\title{
ToxicDocs: a new resource for assessing the impact of corporate practices on health
}

\author{
Nicholas Freudenberg ${ }^{1}$
}

(C) Macmillan Publishers Ltd., part of Springer Nature 2018

In the past century, corporations have contributed to premature death and preventable illnesses globally. A growing body of evidence shows how the practices of corporations and their allies contribute to chronic diseases, injuries, and toxic exposures [1-3]. Public health researchers can chart how business practices such as marketing, product formulation and pricing, and corporate political activity such as lobbying, election campaign contributions, sponsored research, and public relations promote the behaviors, environments, and policies that shape patterns of health and disease [4-6].

One of the main obstacles to creating the scientific evidence needed to reduce the adverse impact of corporations on health has been the extensive efforts of corporations to shield their harmful practices from scrutiny, scientific or public. To achieve this goal, corporations have

- Falsified data, including when Volkswagen lied about its emission control devices [7] and Kobe steel reported fabricated data on the durability and safety of its metal products [8],

- Engaged in 'credibility engineering,' a practice by which corporations seek to repair damage to their credibility by reframing the problem [9],

- Obscured their conflicts of interest to enable them to appear to be a legitimate and disinterested participant in the policy process [10],

- Attacked and harassed critics by hacking their private communications [11], maligning their reputation [12], or threatening lawsuits [13],

- Helped pass laws limiting the public's and scientists right to know [14], and

- Acted vigorously to defeat public health measures [15].

Nicholas Freudenberg

Nick.Freudenberg@sph.cuny.edu

1 CUNY Graduate School of Public Health and Health Policy, 55 West 125th Street, New York, NY 10027, USA 
Fortunately, in response to growing corporate efforts to limit public access to scientific evidence and free debate, researchers, activists, public interest lawyers, and public health professionals have created new ways of collecting, analyzing, and publicizing the evidence, ways that can illuminate what corporations seek to keep in the dark.

The new website, http://www.ToxicDocs.org [16], is an example. It provides scholars and activists with an important new resource to harness the power of new search technologies, worldwide Internet availability, and the growing recognition of corporate practices as a fundamental social determinant of health. By using www. ToxicDocs.org's embedded search methods, investigators can answer legal and scientific questions such as the following: What did corporate executives know about the harmful effects of their products and practices? What steps did they take to reveal or hide this knowledge? And, what was their understanding of the mechanisms by which their practices influenced the health of workers, consumers, and the environment?

Fortunately, http://www.ToxicDocs.org is not the only public source of these data that have until recently been inaccessible. It is part of a growing trove of archives that can assist scholars and activists. Another is Poison Papers that documents the "hidden history of chemical and pesticide hazards in the United States" [17]. The oldest collection is the long-established University of California San Francisco (UCSF) Truth Tobacco Legacy Documents, an archive of 14.7 million documents (85 million pages) obtained from tobacco companies telling about their advertising, manufacturing, marketing, scientific research, and political activities. It is hosted by the UCSF Library and by the Center for Knowledge Management [18]. This archive also includes documents from the pharmaceutical [19] and chemical industries [20].

Other sources provide data on corporate political practices. Open Secrets, a project of the Center for Responsive Politics, tracks money from corporations and others in US politics and how it affects elections and public policy [21]. The Sunlight Foundation uses 'civic technology' (new social and digital media to engage people in politics and policy advocacy) along with open data, policy analysis, and journalism to report on conflicts of interest and other ways that money influences politics [22].

Another development of the past two decades is the emergence of a new cohort of outlets for today's investigative journalists. The journalists at these multimedia organizations produce in-depth investigations of industry practices and their impact on health, the environment, and democracy. The Pro Publica series "Dollars for Docs" [23] has investigated how the pharmaceutical industry pays doctors to encourage them to prescribe their products. The Center for Public Integrity has reported on industry ties and conflicts of interest among scientists who advise the FDA on food safety [24], and the International Consortium of Investigative Journalism published an exposé of global tobacco industry tactics used to subvert government regulation [25]. These and other investigative media outlets have reinvigorated the journalistic and scientific traditions of the last century pioneered by Upton Sinclair, Alice Hamilton, Rachel Carson, and others to reveal corporate secrets to inspire public health reforms. 
For those in public health, ToxicDocs and other new sources of evidence suggest new strategies for research and for educating future professionals, researchers, and advocates. As new technologies, approaches to organizing and analyzing data, and sources of data emerge, research teams will need to include interdisciplinary and intersectoral expertise to deploy these novel approaches. Such teams can identify how corporations influence health. They can develop strategies to monitor, reduce, and, ideally, to prevent harmful practices. While there may still be a place for the nostalgic image of the lone researcher spending long hours in a dusty archive poring over crumbling paper, successful efforts to challenge harmful industry practices will, in the future, require global teams of researchers who can match the breadth of expertise that corporations now deploy to keep their evidence secret.

Universities need to ensure that our students and junior colleagues master data collection, analysis, and reporting techniques that ToxicDocs and similar sites employ. Increasingly, scholars who rely only on peer-reviewed biomedical publications or publicly reported clinical trials for evidence will miss some of today's most important public health developments. Preparing our students for this new world warrants as much effort as meeting the Council on Education for Public Health's new list of competencies.

The creation of ToxicDocs and similar sources signals an important new development in assembling evidence for public health action. Ensuring that we fully realize this potential is an important priority for the public health community.

\section{References}

1. Stuckler D, McKee M, Ebrahim S, Bash S. Manufacturing epidemics: the role of global producers in increased consumption of unhealthy commodities including processed foods, alcohol, and tobacco. PLoS Med. 2012;9(6):e1001235.

2. Moodie R, Stuckler D, Monteiro C, Sheron N, Neal B, Thamarangsi T, Lincoln P, Casswell S, Lancet NCD Action Group. Profits and pandemics: prevention of harmful effects of tobacco, alcohol, and ultra-processed food and drink industries. The Lancet. 2013;381(9867):670-9.

3. Freudenberg N. Lethal but legal: corporations, consumption, and protecting public health. New York: Oxford University Press; 2014.

4. Harris JL, Pomeranz JL, Lobstein T, Brownell KD. A crisis in the marketplace: how food marketing contributes to childhood obesity and what can be done. Annu Rev Public Health. 2009;30:211-25.

5. Vernick JS, Teret SP. A public health approach to regulating firearms as consumer products. Univ Pa Law Rev. 2000;148(4):1193-211.

6. Neuman M, Bitton A, Glantz S. Tobacco industry strategies for influencing European Community tobacco advertising legislation. The Lancet. 2002;359(9314):1323-30.

7. Oldenkamp R, van Zelm R, Huijbregts MA. Valuing the human health damage caused by the fraud of Volkswagen. Environ Pollut. 2016;212:121-7.

8. Soble J, Boudette N. Kobe steel's falsified data is another blow to Japan's reputation. New York Times; 2017, p. A1.

9. Penders B, Nelis AP. Credibility engineering in the food industry: linking science, regulation, and marketing in a corporate context. Sci Context. 2011;24(4):487-515.

10. Burlandy L, Alexandre VP, Gomes FD, Castro IR, Dias PC, Henriques P, Carvalho CM, Castro Júnior PC. Health promotion policies and potential conflicts of interest involving the commercial private sector. Ciencia \& saude coletiva. 2016;21(6):1809-18.

11. Perlroth N. Spyware's odd targtes: backers of Mexico's soda tax. New York Times; 2017, p. A1. 
12. Rosner D, Markowitz G. Standing up to the lead industry: an interview with Herbert Needleman. Public Health Rep. 2005;120(3):330-7.

13. Pring GW. SLAPPs: strategic lawsuits against public participation. Pace Environ Law Rev. 1989;7:3.

14. Landrigan PJ, Benbrook C. GMOs, herbicides, and public health. N Engl J Med. 2015;373(8):693-5.

15. Savell E, Gilmore AB, Fooks G. How does the tobacco industry attempt to influence marketing regulations? A systematic review. PLoS ONE. 2014;9(2):e87389.

16. Rosner D, Markowitz G, Chowkwanyun M. Guest Editorial: ToxicDocs (www.ToxicDocs.org): from history buried in stacks of paper to open, searchable archives online. J Public Health Policy [special section] "ToxicDocs: opening a new era of evidence for policies to protect public health" (Guest Eds. Rosner D, Markowitz G, Chowkwanyun M). 2018;39(1). https://doi.org/10.1057/s41271-017-0106-8.

17. The Poison Papers. Introduction, 2017. https://www.poisonpapers.org/the-poison-papers/.

18. Truth Tobacco Industry Documents. History. https://www.industrydocumentslibrary.ucsf.edu/ tobacco/about/history/.

19. UCSF Industry Documents Library. Drug industry documents. https://www. industrydocumentslibrary.ucsf.edu/drug/.

20. UCSF Industry Documents Library. Chemical industry documents. https://www. industrydocumentslibrary.ucsf.edu/chemical/.

21. Center for Responsive Politics. Open secrets. About. https://www.opensecrets.org/about/.

22. The Sunlight Foundation. About. https://sunlightfoundation.com/about/.

23. Ornstein C, Groeger L, Tigas M, Jones RG. Dollars for docs, Pro Publica; 2016. https://projects. propublica.org/docdollars/.

24. Young C, Quinn E. The misinformation industry: food safety scientists have ties to big tobacco. Center for Public Integrity; 2015. https://www.publicintegrity.org/2015/04/15/17144/food-safetyscientists-have-ties-big-tobacco.

25. Sandoval R. Smoke screen: the tobacco lobby goes global. International Consortium of Investigative Journalists. November 10, 2010. https://www.icij.org/investigations/smoke-screen/.

Nicholas Freudenberg MPH, DrPH, is Distinguished Professor of Public Health at CUNY, Director of the CUNY Urban Food Policy Institute, and author of Lethal but Legal, Corporations: Consumption, and Protecting Public Health (Oxford, paperback 2016). 